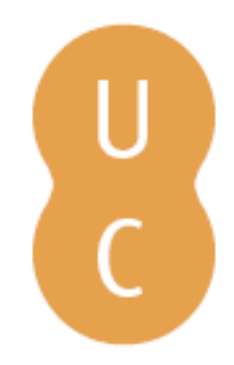

\title{
Rompalina
}

\section{Susceptibility of forest fire in urban area of Uba, MG, Brazil}

$\begin{array}{ll}\text { Autor(es): } & \text { Torres, Fillipe Tamiozzo Pereira; Ribeiro, Guido Assunção; Silva, Elias; }\end{array}$

Publicado por: Imprensa da Universidade de Coimbra

URL

persistente: URI:http://hdl.handle.net/10316.2/34283

DOI: $\quad$ DOI:http://dx.doi.org/10.14195/978-989-26-0884-6_104

Accessed : $\quad$ 26-Apr-2023 10:40:08

A navegação consulta e descarregamento dos títulos inseridos nas Bibliotecas Digitais UC Digitalis, UC Pombalina e UC Impactum, pressupõem a aceitação plena e sem reservas dos Termos e Condições de Uso destas Bibliotecas Digitais, disponíveis em https://digitalis.uc.pt/pt-pt/termos.

Conforme exposto nos referidos Termos e Condições de Uso, o descarregamento de títulos de acesso restrito requer uma licença válida de autorização devendo o utilizador aceder ao(s) documento(s) a partir de um endereço de IP da instituição detentora da supramencionada licença.

Ao utilizador é apenas permitido o descarregamento para uso pessoal, pelo que o emprego do(s) título(s) descarregado(s) para outro fim, designadamente comercial, carece de autorização do respetivo autor ou editor da obra.

Na medida em que todas as obras da UC Digitalis se encontram protegidas pelo Código do Direito de Autor e Direitos Conexos e demais legislação aplicável, toda a cópia, parcial ou total, deste documento, nos casos em que é legalmente admitida, deverá conter ou fazer-se acompanhar por este aviso.

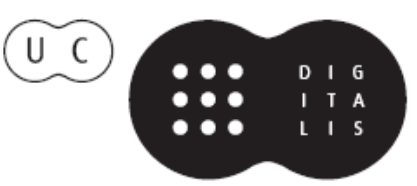




\section{ADVANCES IN}

Forest Fire

\section{RESEARCH}

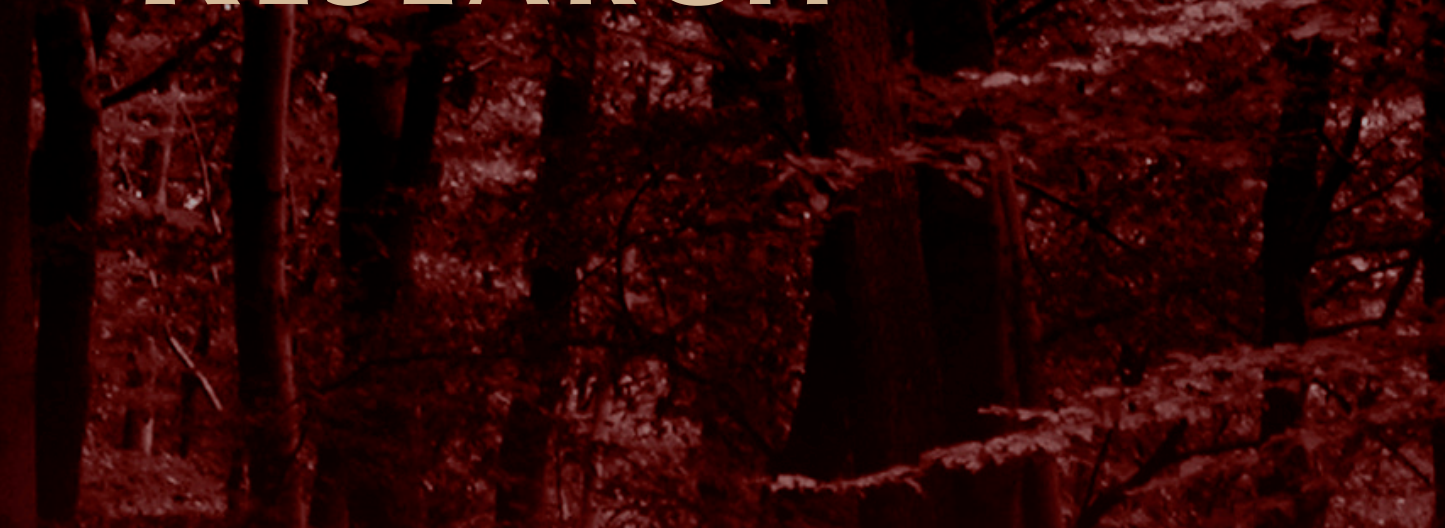

\section{DOMINGOS XAVIER VIEGAS}

\section{EDITOR}




\title{
Susceptibility of forest fire in urban area of Uba, MG, Brazil
}

\author{
Fillipe Tamiozzo Pereira Torres, Guido Assunção Ribeiro, Elias Silva, Sebastião Venâncio Martins \\ ${ }^{a}$ Universidade Federal de Viçosa, DEF, campus universitário 36570-000, torresftp@yahoo.com.br, \\ gribeiro@ufv.br, eshamir@ufv.br, venancio@ufv.br
}

\begin{abstract}
The aim of this study was to produce a map of susceptibility to fires in vegetation within the urban perimeter of the city of Uba, MG, Brazil, with the use of information related to topography, land cover and land use and the proximity of access roads and urban areas, using GIS techniques. From the validation of the generated cartogram, it was observed that $80 \%$ of cases were located in areas of high and very high risk, $15 \%$ in mediumrisk and $5 \%$ in areas of low and very low risk. Was observed in this study that the largest number of occurrences is concentrated near urban areas. In other studies, these authors found that, besides the favourable physical environment it is necessary a causative agent to fire occur. In area of very high or very low risk, the event will only occur from an initial cause or source of heat. This mapping will serve as a tool for establishing public policies to prevent power, acting in promoting awareness and control measures in the areas of highest risk.
\end{abstract}

Keywords: Vegetations fires, susceptibility, map.

\section{Introduction}

Fire is a growing problem in the remaining tropical forests in the world. Despite years of scientific study and all the media attention in relation to forest fires, the effects they cause to the environment have also been ignored (Silva et al., 2003).

Fires in vegetation generate various economic, landscape and ecological damage and can occur in protected or conservation areas, farms, roadsides, proximity to urban areas and reforestation areas, besides other places (Fiedler et al., (2006). Anyway, fires occur when several factors associated with combustion and fire propagation become favorable to the ignition and spread of flame (Nogueira et al., 2002).

There are two types of factors that determine the degree of fire danger. The constant factors that are represented by the type of fuel, which involves different types of vegetation and topography and the variable factors that are represented by atmospheric conditions (Torres et al., 2011). The slope, aspect and the use and occupation of land are examples of these variables.

According to Batista (2000), the topography influences the climate and determines the type of fuel. Considering that fire behavior is largely the result of climate and fuel available, it can be said that the topography also has a decisive influence on fire behavior.

Surfaces with different orientations and slope receive different amounts of solar radiation compared to a horizontal surface at the same location and time of year (Torres \& Machado, 2011). The studies of Torres et al. (2010a) shown that the concentration of largest number of fires on the North (43\%), followed by Western a (27\%), East (18\%) and South aspect (12\%) with fewer occurrences. This is due the sun, during most of the year, culminates in Zenith north of the city, because of latitudinal position. This factor tends to raise the temperature in the North aspect influencing more fuel load and fire occurrences. Regarding the slope Ribeiro et al. (2007) shown that the increased of the fire intensity in this areas is due to the approaching flames and fuel compared with smooth areas, heating the fuel quickly. 
According to Viegas (2004), the spread of fire in slopes is distinct from that in areas without slope due to the effect of additional factors such as convection and radiation behavior. If there is slope and the presence of wind, the propagation rate tends to increase.

In addition to relief, the fuel is crucial in the fire occurrence. Evaluating coverage torched in the city of Uba (MG), Torres et al. (2010a) observed that the most forest vegetation tends to hold moisture better than herbaceous, recording $80 \%$ of the occurrences of fires in fields and pastures and $5 \%$ in forests.

The type of material and their arrangement facilitate the ignition and spread of fire. The thinner material has lower ignition temperature and loses their moisture faster (Nunes, Soares \& Batista, 2006), facilitates the start of the fire and accelerates its spread. Also according to these authors, the proximity and uniform distribution of the fuel particles facilitate the spread, also favoring the occurrence of fire on the fields, pastures, and urban vegetation areas.

On the other hand, bushes or trees intercept the radiation, reducing the temperature of the air and the fuel in its interior (Nunes et al., 2008). They also act as a barrier, preventing the free passage of air currents, reducing the wind speed inside. This reduces evaporation, making the drying of the fuel. Furthermore, transpiration of forest material provides an increase in relative humidity in the forested area.

However, it is not enough that the factors directly associated with the occurrence of forest fires are favorables, the initial flame is necessary to fire occurrence. Thus, any action to prevent forest fires should seek the elimination of its causes (Nogueira et al., 2002).

According to Soares and Cordeiro (1974), Soares and Santos (2002), Bonfim, Ribeiro and Silva (2003), Santos, Soares and Batista (2006), and Torres et al. (2010b), the main cause of fires is human activity, such as smoking, burning to clean, incendiary fires and recreation. Thus, next to roads and urban areas tend to be more susceptible to fire occurrences.

Because of the constant character of the listed factors (slope, aspect and land use), they become valuable in establishing susceptibility maps to fires. It is essential to know where the fires occur to determine the areas of high risk or high susceptibility (Soares and Santos, 2002) for these regions by establishing specific programs. The risk zoning or fire risk maps according to Batista (2000) have been used very effectively as a fundamental tool in the rational planning of resources for prevention and pre-suppression of fires on vegetation.

Faria, Silva and Goes (2003) affirm that the use of tools linked to a Geographic Information System (GIS), allows increase knowledge about the relationships between environmental phenomena, estimating risk areas, potential environmental and defining zoning. The cartograms generated provide a layer on the various components of the environment, such as slope, use and cover, soils, geomorphology, and others, besides to allow the overlap of the generated maps.

The aim of this study was to produce a map of susceptibility or risk to fires in vegetation inside the urban area of Uba city (MG), using informations related to relief, use and land cover. This mapping will serve as a tool for establishing public policies for prevention, acting in the public awareness of power as well as control measures in the areas of highest risk.

\section{Methods}

The Municipality of Uba is located in the physiographic mesoregion denominated Zona da Mata Mineira, Minas Gerais State, Brazil. It lies between latitudes $21^{\circ} 16^{\prime}$ to $20^{\circ} 57^{\prime}$ south and longitudes $43^{\circ} 07^{\prime}$ to $42^{\circ} 57^{\prime}$ west. Its length is approximately 40,750 hectares and its population is about the 101,466 inhabitants (IBGE, 2010).

The topography is represented by areas of strong wavy slope, comprising about 16,556 hectares (40.6 $\%$ ) of its entire territory. However, other 11,354 hectares $(27.9 \%)$ can be considered flat whereas 8,790 hectares $(21.6 \%)$ has an intermediate topography. The remaining area $(4,050$ hectares, $8.9 \%)$ has a mountainous structure. 
The vegetation type is compound by pasture cover an area of $75,51 \%$, followed by brushwood (capoeira) and woods with $16.2 \%$ and agriculture with $4.9 \%$.

The susceptibility cartogram of fires was done using ArcGIS 9.3 software to generate the maps of Slope, Aspect and Use and Occupation of the soil. These maps were overlaid, allowing the determination of more susceptible areas to fires.

In this sense, to construct the maps of declivity and exposure of slopes was produced a Digital Elevation Model (DEM) (Figure 1) by interpolating the contours of 10 - 10m, extracted from Aerial Images Orthorectified range of 1:10,000, November 2005.

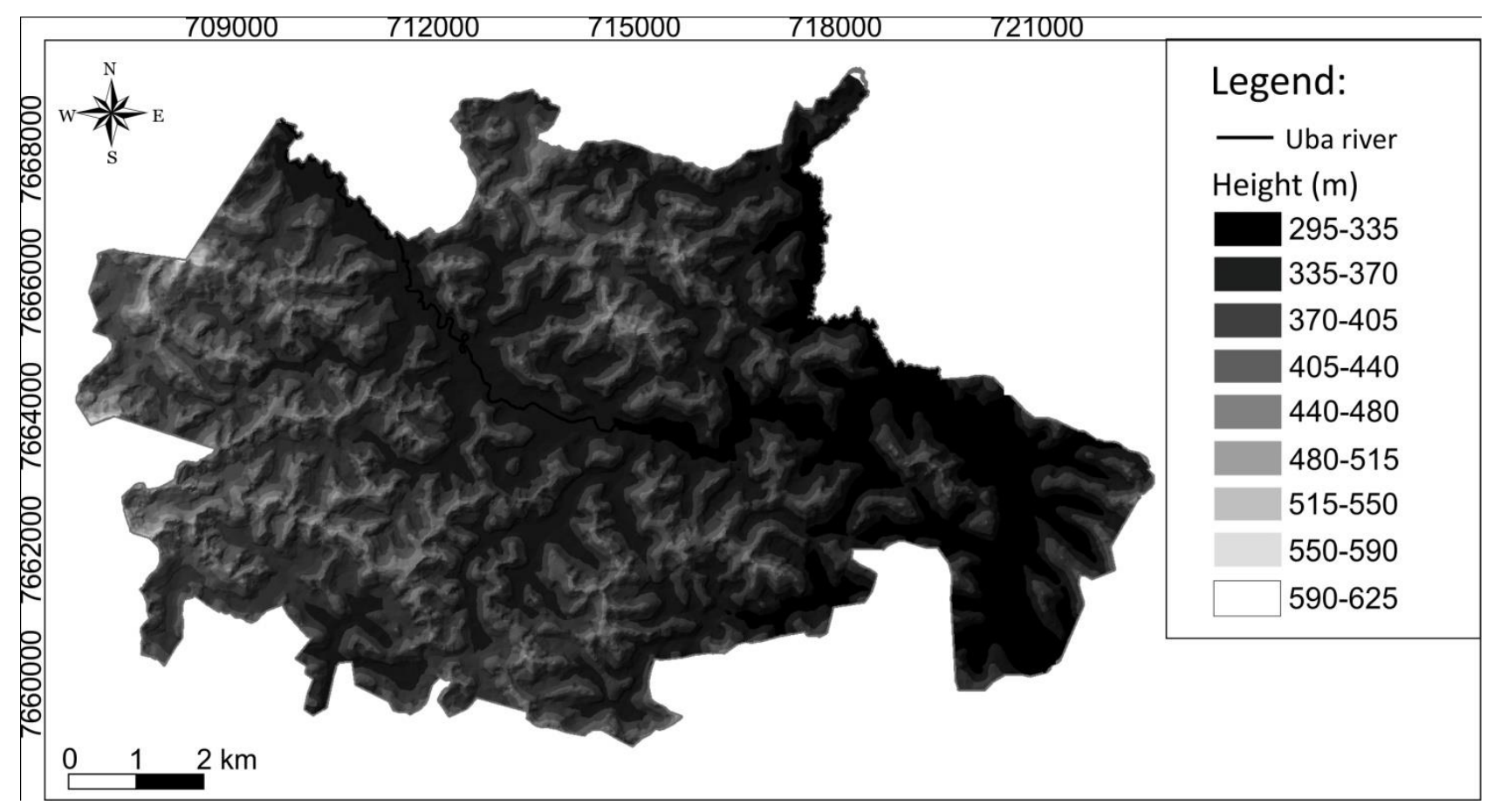

Figure 1. Modelo Digital de Elevação do perímetro urbano de Ubá - MG

The land use map was originated by visual interpretation of orthorectified images. They were vectored the major classes of land use in the urban area of the municipality: forest, brushwood (capoeira), pasture, agriculture, water bodies, exposed soil and constructed area. To check the classification performed in the laboratory, georeferenced points in the field were collected, thus ensuring the reliability of the data.

After generation of cartograms regarding declivity (Figure 2), Aspect (Figure 3) and Use and Occupation of the soil (Figure 4), the classes were analyzed relating to each of these maps. Grades were assigned to each of these classes according to weight of respective class of occurrence (Table 1). 


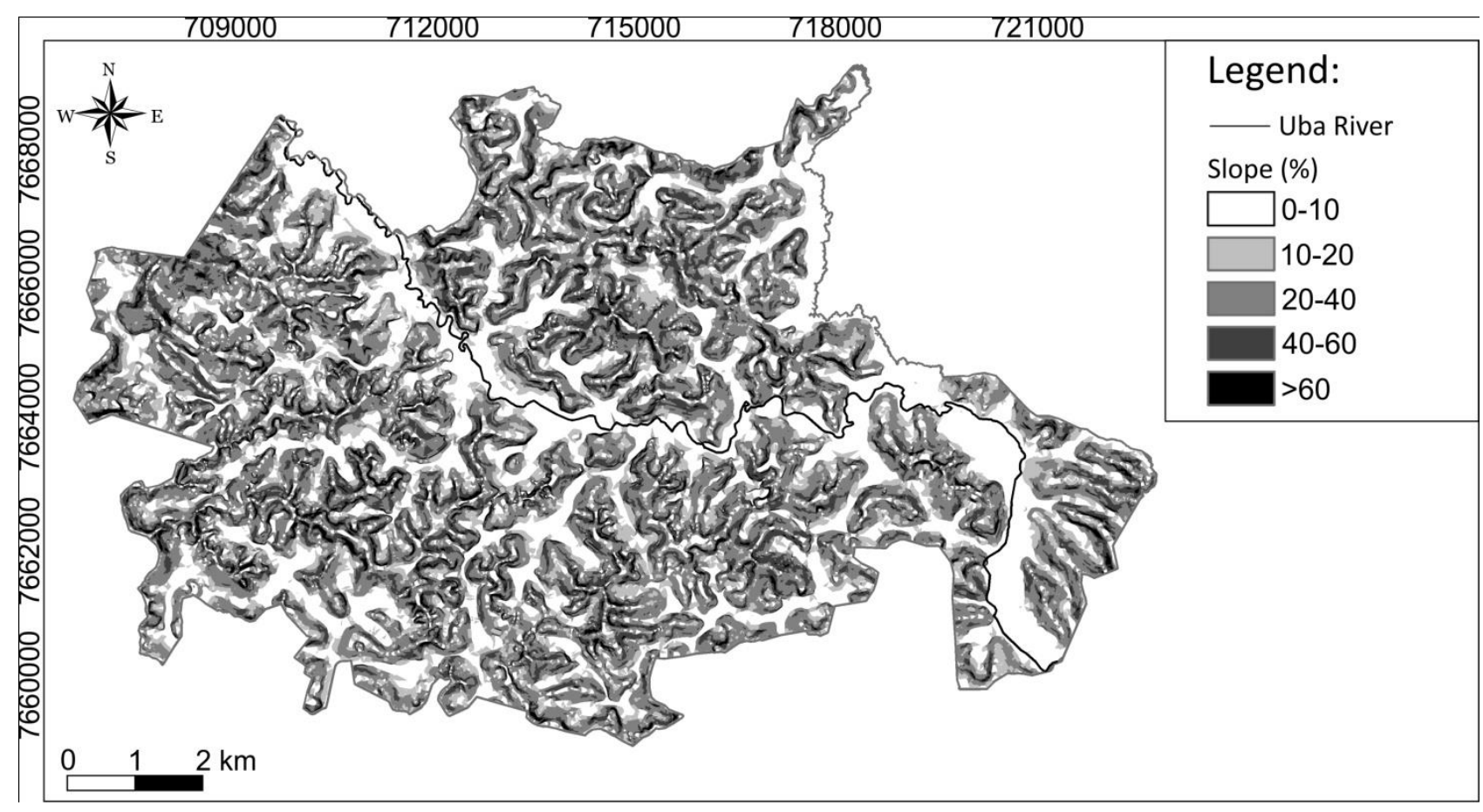

Figure 2. Slope of the urban perimeter Uba - MG

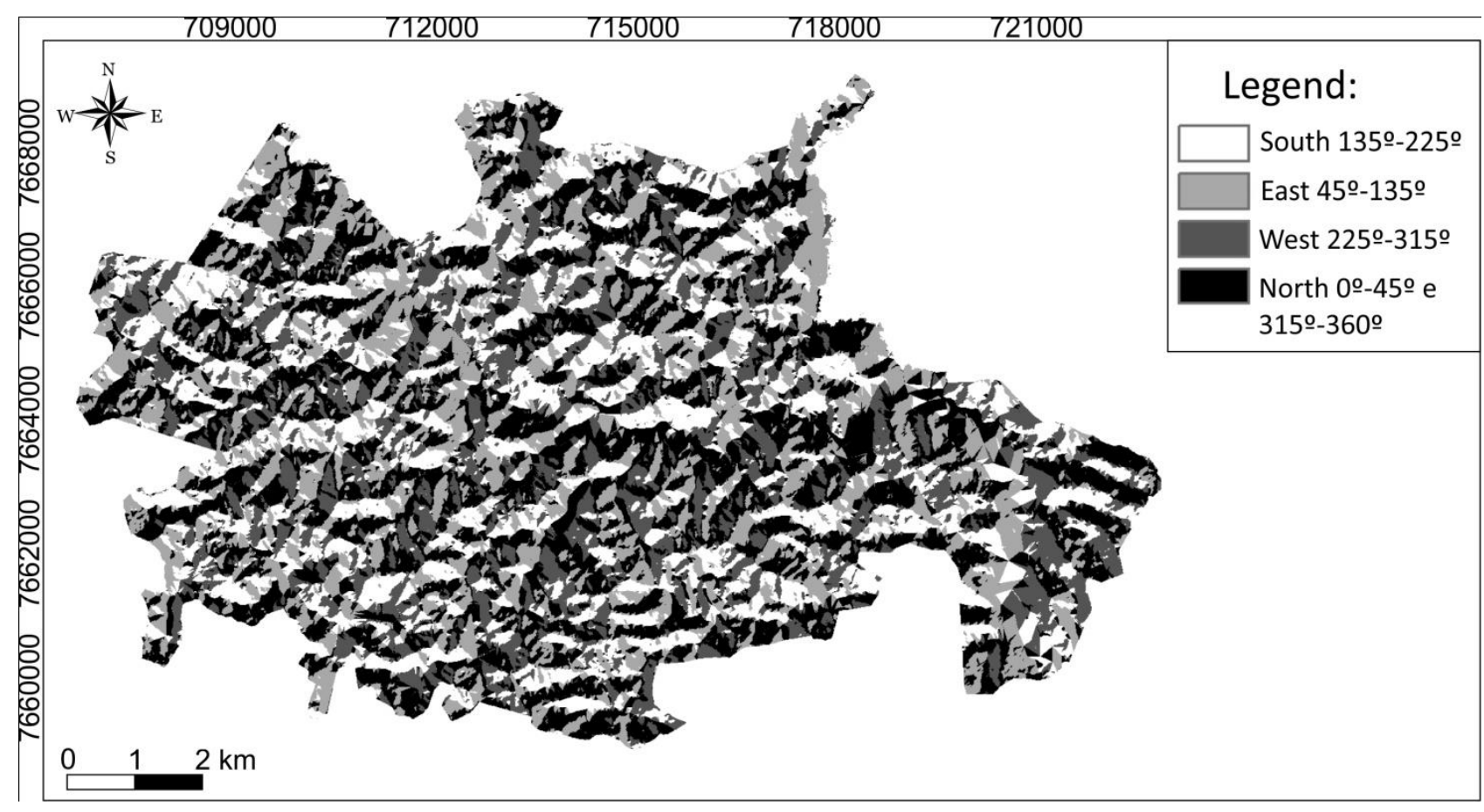

Figure 3. Exposition of the Sun aspects the urban perimeter of Uba - MG 


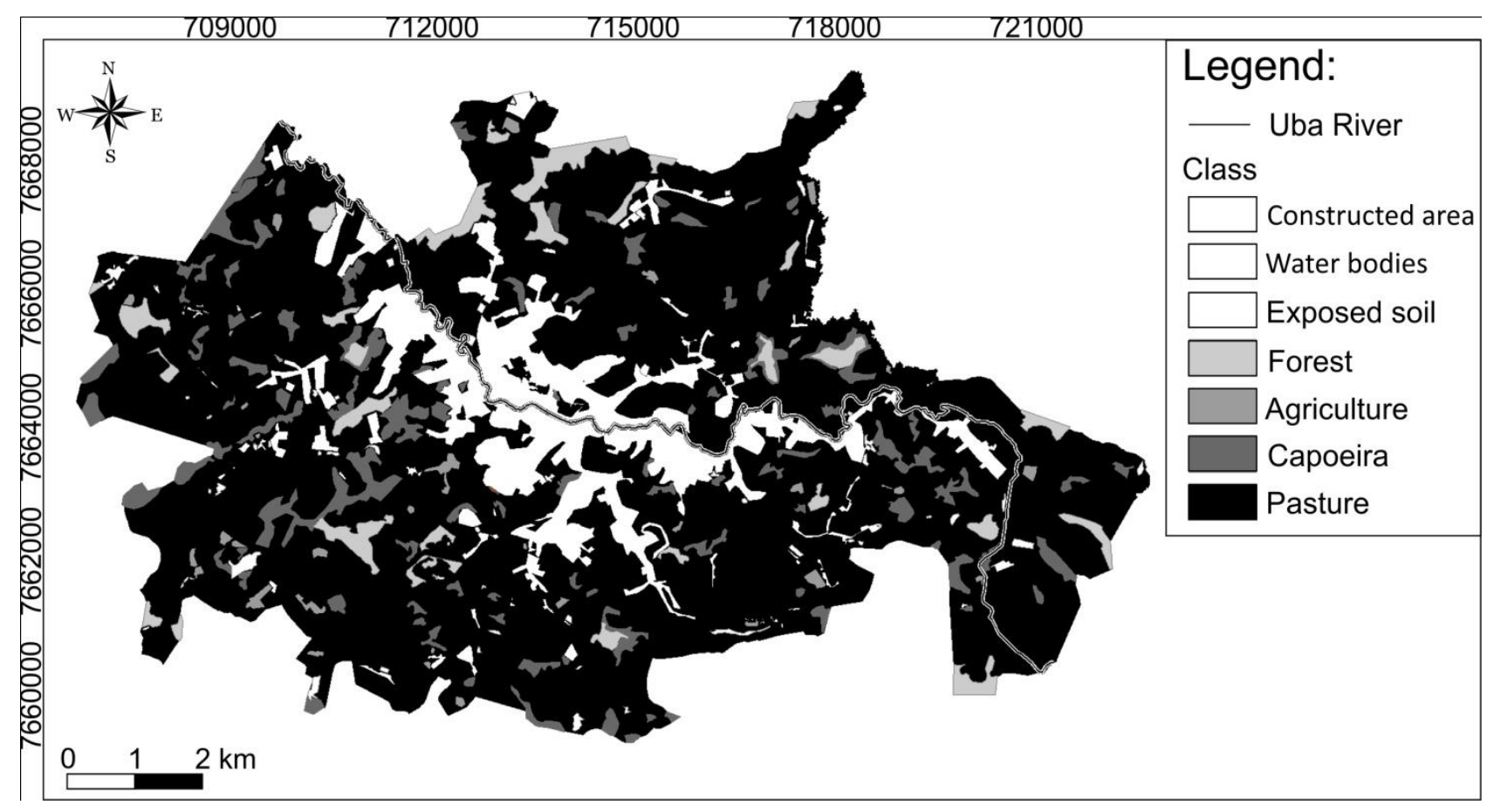

Figure 4. Use and occupation of urban perimeter Uba - MG

Table 1. Table notes the statement of the Fire Risk

\begin{tabular}{|c|c|c|c|c|c|}
\hline \multicolumn{2}{|c|}{ Use and occupation } & \multicolumn{2}{c|}{ Exposition of the Sun } & \multicolumn{2}{c|}{ Slope } \\
\hline Class & Weight & Class & Weight & Class & Weight \\
\hline Forest & 3 & North & 10 & 0 a 10ㅇ & 2 \\
\hline Capoeira & 7 & West & 8 & 10 a 20ㅇ & 4 \\
\hline Agriculture & 5 & East & 6 & 20 a 30 & 6 \\
\hline Constructed area & 0 & South & 4 & 30 a 40 & 8 \\
\hline Exposed soil & 0 & & & $>40$ & 10 \\
\hline Water bodies & 0 & & & & \\
\hline Pasture & 10 & & & & \\
\hline
\end{tabular}

The notations used in Table 1 were based on Torres et al. (2008) and Torres et al. (2010a) who studied the profile of vegetation fires in the cities of Juiz de Fora and Ubá, both located in the Zona da Mata Mineira, Minas Gerais State, Brazil. The data of reclassified maps were overlaid, according to the tree of Figure 5 decision. 


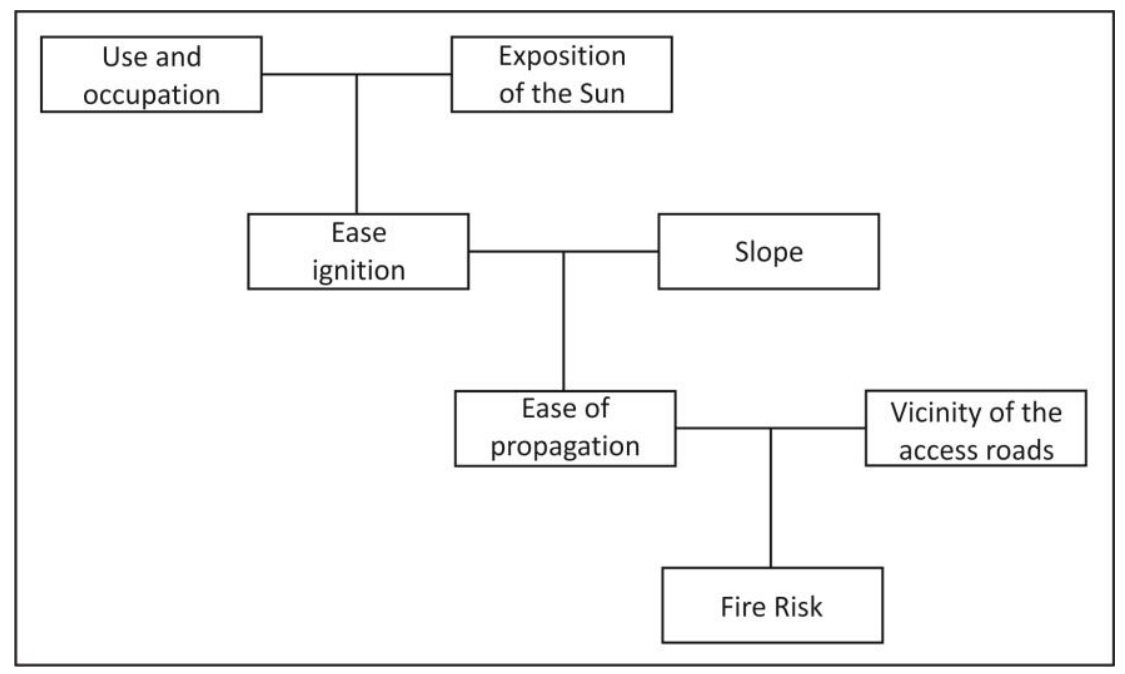

Figure 5. Decision tree for fire risk

The Use and Occupation cartogram was crossed with the Aspect cartogram, both with same weight, generating a Ease Ignition cartogram. Both cartogram has a weight of $66 \%$ when crossed with the Slope cartogram (weight 34\%), generating the Ease of Propagation cartogram.

This cartogram was overlaid to the proximity of roads and urban areas, creating a 15-meter buffer around them. This was based on Torres et al. (2008) that describe the risks of fires in road borders and urban areas peripheries. The final product of these crossings was the cartogram of Susceptibility of Fires in vegetation within the urban area of the municipality of Uba, Minas Gerais Brazil (Figure 6).

\section{Results and Discussion}

The cartogram of susceptibility of fires in vegetation in the urban area vegetation of the municipality of Uba - MG (Figure 6) is supported by hazard classes shown in Table 2.

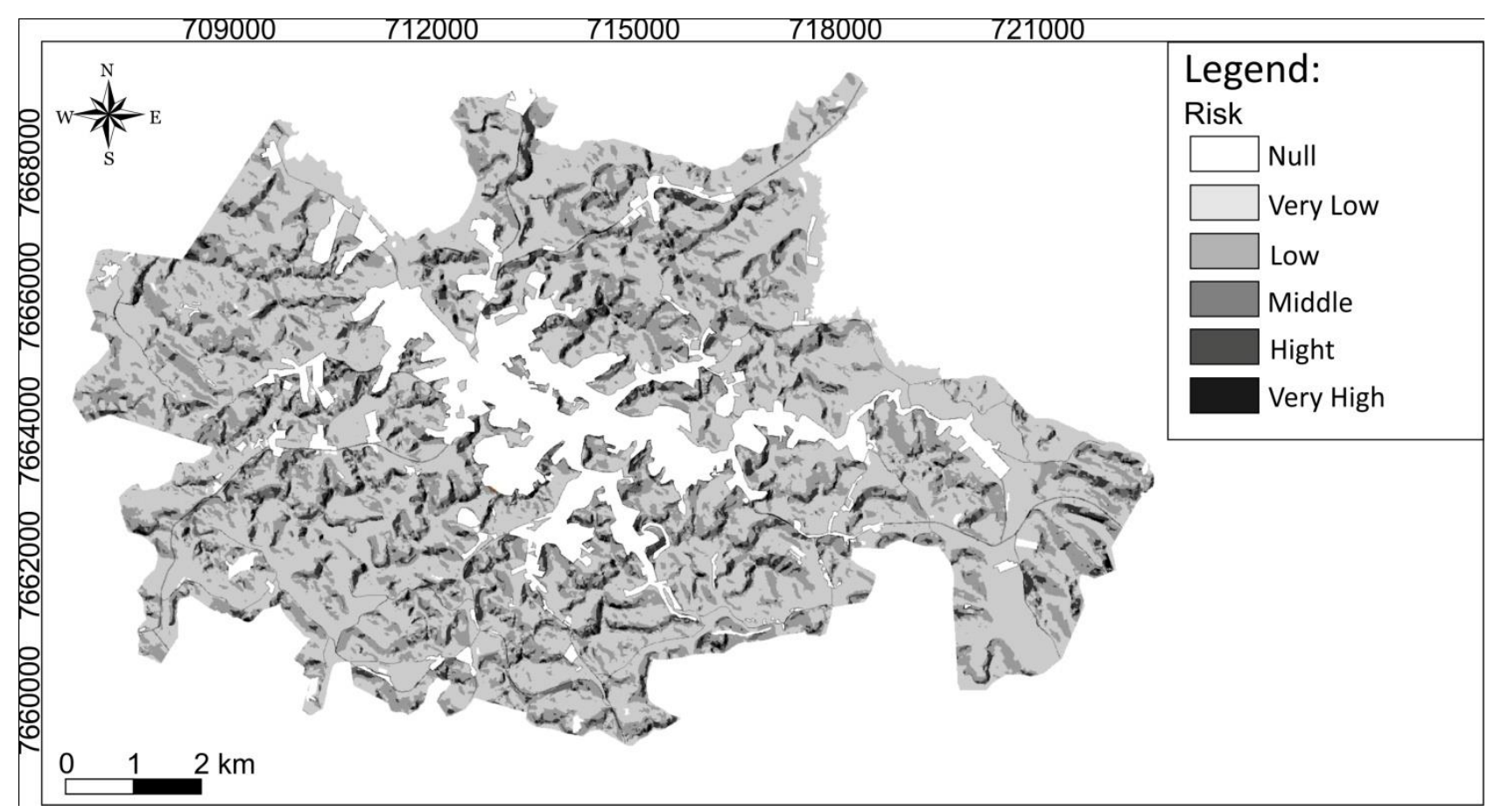

Figure 6. Map of forest fires in the urban perimeter of $U b a-M G$ 
Table 2. Areas according to the class of risk

\begin{tabular}{|c|c|c|}
\hline Class & Ha & $(\mathbf{\%})$ \\
\hline Null & 1276,1 & 13.7 \\
\hline Very Low & 4636,7 & 49,8 \\
\hline Low & 2480,5 & 26,5 \\
\hline Middle & 289,0 & 3,1 \\
\hline High & 555,8 & 5,9 \\
\hline Very High & 96,0 & 1,0 \\
\hline Total & $\mathbf{9 3 3 4 , 1}$ & $\mathbf{1 0 0 \%}$ \\
\hline
\end{tabular}

It is observed that the risk areas are concentrated near urban areas. This is due to the human presence as the main source of ignition of fires. In studies conducted by Torres et al. (2008) and Torres et al. (2011), was identified that although the scenario created by the physical environment (slope, aspect, use and occupation of land) without causal agent there is no occurrence of the fire. On other hands, even in an area classified as very high risk area, the fire will occur only if the initial flame, ordinarily, is associated with cleaning burning, smoking and arson. The same occurs in areas classified as very low risk; if there is the ignition, the risk of fire is high in these areas.

To analyze the effectiveness of the cartogram generated, were used the geographical coordinates of all occurrences in the urban area in the period 2006-2012 (Table 3). It was recorded 732 events in the urban perimeter of study area, with $80 \%$ of those located in areas of high and very high risk and $5 \%$ in areas of low and very low risk. These data demonstrate that the generated map portrays well the situation of vegetation fires in the urban area.

Table 3. Percentage of occurrences according to risk class

\begin{tabular}{|l|c|}
\hline Risk Class & \% of occurrences \\
\hline Null & $0 \%$ \\
\hline Very Low & $1 \%$ \\
\hline Low & $4 \%$ \\
\hline Middle & $15 \%$ \\
\hline High & $28 \%$ \\
\hline Very High & $52 \%$ \\
\hline
\end{tabular}

The results were similar to those of Coura, Souza and Fernandes (2009) for the city of Rio de Janeiro, Brazil. The authors crossed the maps of geomorphology, aspect and land use and they obtained 79\% of occurrences in areas of high risk, $16 \%$ on middle and 5\% in low susceptibility.

\section{Conclusion}

According to the results, it was concluded that:

- The scores and weights used have produced a cartogram that reflects the susceptibility to fires in the urban area of Uba, Minas Gerais, Brazil;

- Areas with Northern aspect, greater slope and near the roads were major points of susceptibilities to occurrences;

- Most of the areas classified as very high risk, as well as incidents recorded by the Fire Department, surrounding the urban area and access roads reflect the high influence of anthropogenic activity;

- the inclusion of changeable factors in the methodology will increase the reliability of the generated cartogram; 
- the cartogram generated serves as a tool to aid the development of strategies for fighting fires in the municipality;

- the methodology is simple and shows likely to be used in other areas with the same issue.

\section{References}

Batista, A. C. (2000). Mapas de risco: uma alternativa para o planejamento de controle de incêndios florestais. Curitiba: Floresta, v.30, n.1, p.45-54.

Bonfim, V. R.; Ribeiro, G. A. E Silva, E. (2003). Diagnóstico do uso do fogo no entorno do Parque Estadual da Serra do Brigadeiro (PESB), MG. Viçosa: Revista Árvore, vol.27 n.1, p.87-94.

Coura, P. H. F.; Sousa, G. M. E Fernandes, M. C. (2009). Mapeamento geoecológico da susceptibilidade à ocorrência de incêndios no Maciço da Pedra Branca, município do Rio de Janeiro. Rio de Janeiro: Anuário do Instituto de Geociências - UFRJ, v.32, n.2, p.14-25.

Faria, A. L. L De; Silva, J. X. Da E Goes, M. H. de B. (2003). Análise ambiental por geoprocessamento em áreas com susceptibilidade à erosão do solo na bacia hidrográfica do Ribeirão do Espírito Santo, Juiz de Fora (MG). Uberlândia: Caminhos de Geografia, v.4, n.9, p.50-65.

Fiedler, N. C. et al. (2006). Avaliação das condições de trabalho, treinamento, saúde e segurança de brigadistas de combate a incêndios florestais em unidades de conservação do Distrito Federal: estudo de caso. Viçosa: Revista Árvore, vol.30 n.1, p.55-63.

IBGE. (2010). Censo Demográfico 2010. Rio de Janeiro: Instituto Brasileiro de Geografia e Estatística.

Nogueira, G. S. et al. (2002). Escolha de locais para instalação de torres de detecção de incêndio com auxílio do SIG. Viçosa: Revista Árvore, v.26, n.3, p.363-369.

Nunes J. R. S.; Soares, R.V.E., E Batista, A. C. (2006). FMA+ - Um novo índice de perigo de incêndios florestais para o Estado do Paraná, Brasil. Curitiba: Floresta, v.36, n.1, p.75-91.

Nunes, J. R. S., et al. (2008). Relação entre a qualidade da paisagem e o risco de incêndios florestais. Curitiba: Floresta, v.38, n.1, p.145-154.

Santos, J. F.; Soares, R. V. E Batista, A.C. (2006). Evolução do perfil dos incêndios florestais em áreas protegidas no Brasil, de 1993 a 2002. Curitiba: Floresta, v.36, nº1, p.93-100.

Silva, J. C. da, et al. (2003) Avaliação de brigadas de incêndios florestais em unidades de conservação. Viçosa: Revista Árvore, v.27, n.1, p.95-101.

Soares, R. V. E Cordeiro, L. (1974). Análise das causas e épocas de incêndios florestais na região centro-paranaense. Curitiba: Floresta, v.5, n.1, p.46-49.

Soares, R. V. E Santos, J. F. (2002). Perfil dos incêndios florestais no Brasil de 1994 a 1997. Curitiba: Floresta, v.32, n.2, p.219-232.

Ribeiro, L. et al. (2008). Zoneamento de riscos de incêndios florestais para a fazenda experimental do Canguiri, Pinhais (PR). Curitiba: Floresta, v.38, n.3, p.561-572.

Torres, F. T. P. et al. (2008). Incêndios em vegetação na área urbana de Juiz de Fora: Minas Gerais. Ubá: Editora Geographica.

Torres, F. T. P. et al. (2010a) Perfil dos Incêndios em Vegetação nos Municípios de Juiz de Fora e Ubá, MG, de 2001 a 2007. Seropédica: Floresta e Ambiente, v. 17, n.1, p.83-89.

Torres, F. T. P. et al. (2010b). Determinação do período mais propício às ocorrências de incêndios em vegetação na área urbana de Juiz de Fora, MG. Viçosa: Revista Árvore, v.34, n.2, p.297-303.

Torres, F. T. P. et al. (2011). Correlações entre os elementos meteorológicos e as ocorrências de incêndios florestais na área urbana de Juiz de Fora, MG. Viçosa: Revista Árvore, v.35, n.1, p.143150.

Torres, F. T. P. E Machado, P. J. de O. (2011). Introdução à Climatologia. São Paulo: Cengage Learning.

Viegas, D. X. (2004). Cercados pelo fogo. Coimbra: Editorial Minerva. 